\title{
1. The theoretical denial of the character of law to the law of nations
}

The destiny of international law is a singular one, setting it apart from the internal laws of States. In general, the disciplines given over to the study of the various branches of municipal law confine themselves to a certain number of particular problems of greater or lesser complexity: but the discipline itself is never called into question. The subjects studied can vary considerably, as can their systematic structure, but no one would think of challenging their very legitimacy as branches of legal knowledge and enquiry, of what we will sometimes refer to below as legal science. Obviously there is, for example, room for debate as to whether legal techniques in commercial law are really distinct from those applicable in civil law, or as to the division and/or dividing lines between the two categories. The regulation of institutions is the subject of particularly lively debate. But there is no dispute as to the raison d'être for such studies, based, as they are, on over two millennia of experience and tradition.

International law is different, because it is problematical in itself. Its very existence as a legal order in the true sense of the term is often flatly denied, so frequently, in fact, that it is impossible to see the denial as a merely arbitrary attitude, or as the intellectual caprice of commentators in search of intellectual sensationalism. This is not a matter of a few solitary voices crying aloud in the desert: quite the reverse, what we have here is a choir in which the singers take various parts, but many of them are highly accomplished performers. In other words, we must recognise that those whom we might call the 'deniers' of international law include eminent philosophers and consummate jurists, some of whom have played major parts in the history of our times. The scale and importance of this negative attitude to international law explains why manuals, treatises and general theoretical studies of the subject have to devote a certain number of pages to proving that their subject is indeed 'legal' in nature. In 1930, Professor Gustav Adolf Walz was even able to devote the 
whole of a substantial volume to the critical examination of these views. ${ }^{1}$ His work is impressive, and in view of its minute attention to detail (sometimes almost excessively minute) and rigorous handling of the arguments, can be considered a classic in this field.

International law thus been left in a somewhat precarious position among the great family of legal disciplines, frequently looking like an intruder laying claim to a place that does not in fact belong to it. So it has to justify itself, and the very fact that the justification is necessary, is by no means the least of the attractions of this branch of law. In this field, the jurist has a more creative role than his counterpart in municipal law. He has to steel himself and keep up his guard. Above all, as we will see, he has to get to the bottom of things and reach satisfying answers to problems concerning the general theory of law, among which the problem of the concept of and basis for international law is only one particular aspect.

Doctrines denying the legal character of international law agree among themselves neither as to their starting point nor as to the arguments upon which they rely. The only points they have in common are their negative conclusions and, up to a point, their common belief that the existence of sanctions against law-breakers is a constituent element of law. ${ }^{2}$ In fact, none of these doctrines deny (and indeed the denial would fly in the face of all experience) that there are indeed rules applicable to the conduct of inter-State relations and, more generally, to the proper ordering of the international community. But they deny that these rules have the quality of law, although, as we shall see, in the view of those we might call the more moderate deniers, the rules amount to embryonic and imperfect law. In other words, among the opponents of international law there are degrees and nuances of opinion as to the intensity of their denial. The deniers can be grouped into three overall categories. The first is the most radical group, denying both that compulsory rules of conduct either do or could exist as between States. For them, in inter-State relations force alone prevails. What is commonly called 'international law' is only an instrument of power politics, a rhetorical device designed to put a fairer

1 Wesen des Völkerrechts und Kritik der Völkerrechtsleugner, Stuttgart, 1930. A Spanish language translation and preliminary study of this work is to be found in A. Truyol y Serra, Esencia del derecho internacional y critica de sus negadores, Madrid, 1943.

2 As C. Gourban puts it in Le problème des sanctions dans l'évolution de l'arbitrage international, Paris, 1923, p. 48: 'Without sanctions, law remains a matter of simple advice or counsel, a theoretical principle of international morality' [our translation]. 
face on brutal realities, in truth an empty expression entirely devoid of nominative value. The two other categories, by contrast, accept that inter-State relations are subject to rules. The issue for them is as to the technical nature of such rules. Some reduce the rules to moral precepts or even mere international courtesies; others consider them to be sui generis, forming a separate system of its own.

\section{A. DOCTRINES REDUCING INTERNATIONAL LAW TO THE EXPRESSION OF SIMPLE POWER-RELATIONSHIPS}

The reduction of international law to the expression of simple power relationships between States is just one particular aspect of the reduction of law to a matter of power or force. There is nothing new about such reductionism. In Antique times, the Greek sophists made themselves apologists for the law of the strongest, in terms such as those Plato attributes to Thrasymachus in Book 1 of the Republic, having him define justice as whatever is useful to those who are in power. This theory was then applied by Thucydides to inter-State relations in several famous passages of his Peloponnesian War, where it was presented as a tradition common to both Athens and Sparta. ${ }^{3}$ For Thucydides, the city was the highest form of earthly moral and social life, and the relationship between cities was governed solely by force. ${ }^{4}$

3 One should note, however, that Plato expressed his opposition to this theory when he argued that States must not commit injustices in their mutual relations. It followed, for example, that war would then be permissible only in self-defence, or to sanction the violation of a right: cf. Nomoi, VIII, no. 829. On this point, see A. Verdross, Abendländische Rechtsphilosophie, Vienna, 1958, p. 39.

4 See especially, in the Peloponnesian War, the impressive dialogue (Book V, 84-113) between the Athenians and the Melians. This ideological standpoint may be compared with that of defenders of international law such as J. L. Brierly, who began his General Course at the Hague Academy with the following weighty sentences:

Aristotle says, in the first chapters of the Politics, that the State is a

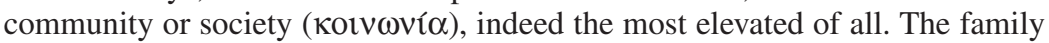
is a community comprising two societies, husband and wife, master and slave. The village is a community of families, and the State $(\pi \mathrm{o} \lambda \mathrm{i} \varsigma)$ a community of villages which, admittedly, came into being in order to make life possible, but whose objective is to make it better. For, Aristotle tells us, just as Man, in the complete flowering of his life that is made possible by his city, is the most 
In modern times this conception was shared, after Machiavelli, ${ }^{5}$ by Baruch Spinoza (1632-1677) in both his Tractatus Politicus and his Tractatus Theologico-Politicus. Spinoza argued that States, living in a state of nature, have a right to do anything they have the effective power to do. The principle of self-preservation (suum esse conservare) was the supreme principal of the moral order, alike for States, for individuals, and for beings not possessed of the faculty of reason. Just as greater fish eat the lesser, ${ }^{6}$ men are natural enemies, and force alone resolves their disputes. Individuals, having coalesced into political societies based on social contracts, have been enabled to escape from this deeply insecure situation, but political societies, as between themselves, have no such way out. The agreements they make among themselves reflect factual circumstances, and if those circumstances change, they can resile from their promises.

In this way of thinking, Spinoza was himself following in the footsteps of Thomas Hobbes, considerably refining the ideas the latter's use of modern science's causative methods. For Spinoza, teleological considerations had no place in reality: they resulted merely from errors in sensory

noble of animals, so, in the same way, when separated from law and justice, he is the vilest. International law is based on the belief that this analysis of the political hierarchy was as yet incomplete. It denies that the State is the highest form of human society, claiming that States themselves are associated in a yet higher community, the civitas maxima. The other element in Aristotle's analysis, the teaching that law and justice can exist only within a society, is one of the eternal and definitive verities of political science. 'In Aristotle's view, whoever is incapable of being a member of a community, or feels so self-sufficient as to have no need of it, is either a brute or a god. The very existence of international law thus rests on the existence of an international community'.

Cf. 'Règles générales du droit de la paix', CCHAIL, vol. 58, 1936-IV, p. 5 [our translation].

5 See in particular chap. XVIII of The Prince, which posterity considered especially scandalous ('Quomodo fides a principibus sit servanda'). This utilitarian doctrine calls for comparison with the maxims of Chanakya Kautilya in ancient India.

6 See the Tractatus theologico-politicus (1677), chap. XVI. On Spinoza's ideas, cf. A. Menzel, 'Spinoza und das Völkerrecht', Zeitschrift für Völkerrecht, vol. 2, 1908, pp. 17 et seq.; A. Verdross, 'Das Völkerrecht im System von Spinoza', Zeitschrift für öffentliches Recht, vol. 7, 1928, pp. 100 et seq.; H. Lauterpacht, 'Spinoza and International Law', BYIL, vol. 8, 1927, pp. 89 et seq. More generally, see J. B. Whitton, 'La règle pacta sunt servanda', CCHAIL, vol. 49, 1934-III, pp. 241 et seq. 
perception. Spinoza recognized only the working of causative laws, ${ }^{7}$ and this was the fundamental reason why he reduced law to fact. Facts alone are subject to the laws of causality: the 'ought' is not subject to them, because its sole basis is to be found in the conceptual world of finalities. At the factual level, law and power are identical, power indicating the exact measure of the causative law: what you have the power to do, and do effectively, is the indisputable causative measure of reality. From this mechanistic perspective, what you 'can' do causatively merges into what you 'can' do normatively. Hence the deep identification between law and power: the law is power, and only power can generate law. Is there then no escaping the anarchic violence of such a state of nature? On that point, Spinoza is at one with Hobbes: given that the state of nature is a state of violence, it is better for men to live according to reason, i.e., by

7 In this respect he shares the orientation of the moral sciences towards the mathematical and empirical sciences in early modern times. Now the equation was: verum ipsum factum. Francis Bacon (1561-1626) was one of the most typical representatives of this current of thought: Novum Organum (1620). Cf. Verdross, supra note 3, p. 98. At the end of the mediaeval period, the mechanical and causative methodology of the natural sciences supplanted finalist thinking. Reality became separated from the layer of values to which finalist thinking had accorded such a fundamental place, so that what remained were purely physical phenomena, observable in accordance with the laws of physics. The understanding and description of such a reality thus became an empirical matter. Everything was to be broken down into its smallest elements, so as to allow the analysis of cause and effect throughout the whole. This method was also applied to social phenomena, as for example to the State (cf. Hobbes, De cive, Preface). This was an age in which the idea of matter constituted by atoms came to the fore, an age of infinitesimal calculation. The universal was no longer the centre of attention: on the contrary, the concern was now with individualities, with the particular (nominalism). The human mind now concentrated on what could be observed through the senses and described by reference to the laws of causation. This exclusive concentration on that which could be empirically verified ended up, so far as law was concerned, in the conclusion that power, and the act by which power legislates positively, were the 'cause' of all legal norms and, by extension, that they formed the foundations of law. In the nineteenth century this integrated positivist doctrine finally came together. A single example illustrates the point. In mediaeval times, under the influence of finalist thinking, it was thought that an object transited through space, whether upwards or downwards, according to laws inherent to it. The impetus given to the object, e.g., by pushing it (and the impetus could, moreover, be contrary to 'nature') was perceived only as the external occasion, and not as the cause or vector behind the movement. Galileo, using the new causative methodology, broke down the movement and analysed its causes, thus discovering the law of gravity, famously verified at the Tower of Pisa. 
submitting to the power, enforced ultimately by violence, of a State which will maintain the social order. The passage from the state of nature to the State thus rests on a compact, a pactum subjectionis. The status civilis replaces the raw strength of the individual under natural laws with the power of a centralised authority. The equation 'power = law' continues to hold, but instead of being applied to each person individually, it now applies to the State, and the State alone. Is the power of the State then absolute, as Hobbes thought? In principle, yes. But Spinoza adds that the strongest State will be one which makes reasonable laws and prospers in consequence, not one which, decreeing arbitrary laws, will sooner or later be doomed to collapse. ${ }^{8}$ Here, then, Spinoza counsels reason and moderation, though such counsel may or may not be heeded, for it is not binding and there is nothing to compel the State to follow and comply with it.

The experience of civil war and the disorders associated with the structural transformation of European societies at the end of the mediaeval period gave rise, both in Hobbes and Spinoza, to theories of State absolutism. This theory of 'absolute' power based on force resulted, in the case of both these philosophers, from their visceral fear of disorder. The State must be in control, not sharing the sword with anyone, and the State is the home of the legal order. Since so-called 'international law' is not sanctioned by any kind of force, it is not truly a legal phenomenon. Spinoza softens these rigorous conclusions slightly by adding that, nevertheless, the more numerous are the States that are parties to a peace treaty, the less each will have to fear from any other party, given that their respective capacities to make war will be pro tanto reduced. This comment gives us a glimpse of the beginnings of a movement to bypass the current state of anarchy by means of an embryonic international 'social contract', one that might ultimately become generalised. Here too, however, law retains its tributary position in relation to effective force. Spinoza never goes back on his initial equation of law to both effective and deontological power.

In the period we are considering, similar doctrines continued to be propounded by a series of authors, amongst whom Lasson, Gumplowicz, Lundstedt and Olivecrona are of particular interest. The floreats of the first two occurred in the second half of the nineteenth century and the start of the twentieth. Lundstedt and Olivecrona were writing after World War I. Lasson's theory reflected the neo-Hegelianism that had such a considerable influence on European thinking in the nineteenth and early

8 Tractatus politicus, chap. III, $§ 7$. 
twentieth centuries, especially in countries such as Italy and Germany. Gumplowicz's theory is of a materialist and sociological type, and some of its elements and results are similar to Marxist conceptions. The theories of Lundstedt and Olivecrona are examples of a current of rigorous criticism of metaphysics generally, and of Hegelian idealism in particular, and are oriented towards an extreme kind of empiricist positivism.

\section{Adolf Lasson (1832-1917) and Hegelianism?}

For many years, the German legal philosopher Adolf Lasson was a professor at the University of Berlin. At first he was concerned with international law only within the general context of the system of legal philosophy written up in a work he published in 1882. However in 1871, he wrote a book specifically concerned with international law; the impressive and rigorous thinking set out in it has caused it to remain a classic in its field. His title, 'International Law - Principle and Future' (Prinzip und Zukunft des Völkerrechts) hardly does the work justice, given that Lasson formally denies not only the current existence of international law, but also the possibility of its coming into existence at some future time.

Lasson's philosophy of law built on Hegel. ${ }^{10}$ A growing vogue for Hegel had characterised developing legal thinking since the end of the

9 It will be remembered that for Hegel, the State was the highest incarnation of the objective spirit, so that it could not submit to law not emanating from itself. From this basis he developed a gigantic philosophy of immanence: everything is in the spirit itself, which progresses through the dialectic of history. International law, for its part, could be founded only on the will of the State in so far as that will accorded with the wills of other States: it is was thus an external form of State law. Its validity depended on the wills of the various States, and for each State, its own well-being was the supreme law (Philosophy of Right, 1821, $\S 336)$. The State, then, can unilaterally resile from the norms binding on it whenever it considers it useful or necessary to do so, so that, in effect, international law is binding on it only so long as it wishes to be bound. International law is thus precarious, and only war can resolve the conflicting claims of States (ibid., §334). Warfare thus works as a kind of tribunal of history, in which cultures clash and victory goes to the strongest: see infra, chap. 3.A.

10 On the influence of Hegelian idealism in nineteenth and twentieth century Europe, see, for a brief overview, Verdross, supra note 3, pp. 154-5; and for a more detailed examination, E. Opocher, Lezioni di filosofia del diritto, Padua, 1983, pp. 135 et seq., 174 et seq., 211 et seq. (Italian neo-idealism). In Italian, 
nineteenth century, especially in Germany (Julins Binder, Hans Freyer), the Netherlands (Gerardus Bolland), but even more so in Italy, with thinkers of the stature of Bennedetto Croce and Giovanni Gentile, not to mention their master, Bertrando Spaventa. Even England, such infertile soil for continental philosophy, did not escape (as witness, among others, the works of James H. Stirling, Francis H. Bradler and Bernard Bosanquet) the seductions of the Hegelian system, much of whose appeal was due to its grandiose architecture. The USA, for its part, also drew, in the person of Josyah Royce, on Hegelian sources, as a counterweight to the prevailing pragmatism. When it came to international law, Hegel's philosophy was to find echoes all the more durable for being sometimes even outside those Hegelian doctrines that were directly concerned with the metaphysics of the State. One might repeat, of Hegel's powerful systematic thinking, the words of the poet: 'C'est un cri répété par mille sentinelles, Un ordre renvoyé par mille porte-voix' ['A cry repeated by a thousand sentinels; an order delivered by a thousand messengers'].

Although Lasson drew support from Hegel's philosophy of the State, he went beyond it when it came to inter-State relations. According to Hegel such relations are subject to legal rules, even though such rules are only an externalised form of State law, not international law in the true sense of the term. For Lasson as for Hegel, the State was the supreme incarnation of the objective spirit, the reality of the moral ideal. In other words it represented absolute power on earth, and as such, could not, ex hypothesi, submit to a normative order superior to itself. From two points of view, the State was an end in itself: first, because it ensured order and prevented anarchy; and second, because it represented the ultimate and inalienable expression of a nation's life and culture, as realised in the unique vessel that was history. As an end in itself, the State had no other guiding principle of conduct than its own interests. When the interests of two States were in fundamental conflict, only war could resolve the question. War was thus the tribunal of history, delivering the final judgment of the respective rights and destinies of the peoples involved in the dispute. Inter-State relationships were seen as characterised by latent hostility.

For present purposes, the really important feature of this view is that the situation is not presented as a transitory one that can eventually be superseded by subsequent developments. In Lasson's view it was simply the nature of things, i.e., one of the consequences of the fact that the very

one can mention authors such as Croce, Gentile, Cammarata, Battaglia, Volpicelli, Maggiore, etc. 
essence of the State was the supreme incarnation of the objective spirit. The State could not accept any limitation on its sovereignty. Any pretence to escape from that state of affairs by establishing a universal State was, Lasson added, vain, because such a State was contrary to the nature of things, which required the objective spirit to realise itself in a plurality of State cultures.

It was true that the obvious selfishness of States would lead them, in times of peace, to enter into agreements with a view to harmonising their interests, to the extent that it was practicable to do so. But such agreements did not constitute rules of law, because - leaving aside the fact that they affected only secondary interests - they were nothing more than the pure and simple expression of the balance of forces. They retained their raison d'être only to the extent that the balance of forces did not change. This meant that treaties between States could not be considered anything more than rules of prudent politics, with which States would comply so long as it remained in their interest to do so. They could not be judged from the point of view either of justice or even of formal legality, in a way that would oblige States to respect them, but only from the point of view of the adequacy (Sachgemässheit) with which they reflected the real balance of forces. In Lasson's view they were 'just' to the extent that they adequately reflected that balance, and that was a question that only the State itself could judge. If the balance of power changed, war was in many instances the only option of an aggrieved State. Resort to war was an inalienable prerogative of State sovereignty. War was also, for Lasson as for Hegel before him, an instrument of cultural selection in the sense that it constituted one of the moments in which 'World Spirit' gives expression to a divine judgment as between the warring States. Lasson devoted another of his works, entitled Das Kulturideal und der Krieg (2nd edn, 1906), ${ }^{11}$ to war as an instrument of that absolute or world spirit. These doctrines had a profound cultural influence in Germany and Italy at the end of the nineteenth and beginning of the twentieth century. Intellectually, it is difficult to avoid seeing in them one of the crucibles from which the intimate connection between war and the exaltation of force in both countries would emerge in the first half of the twentieth century.

11 For a closer examination, cf. Walz, supra note $1, \S \S 8$ and 29. 


\section{Ludwig Gumplowicz (1838-1909)}

If Adolf Lasson approached the problem of international law from the basis of idealist metaphysics, Ludwig Gumplowicz, by contrast, did so from the basis of positivist naturalism, invoking Charles Darwin and Herbert Spencer. Gumplowicz was a Polish sociologist, born in 1838, who in 1875 became a Professor at the University of Graz, finally dying of cancer in 1909. His interest in international law was confined to the context of a general theory of the State, in a book first entitled Philosophisches Staatsrecht (1877), and then, in the third edition (1907), Allgemeines Staatsrecht. As already indicated, Gumplowicz was first and foremost a sociologist, although he also produced a history of political doctrines.

Gumplowicz started from a naturalistic conception, according to which culture was the product of struggles between different elements of humanity. First, there were struggles between differentiated primitive groups, then the struggle between States that emerged from the submission of some races to others, and then, finally, class struggles within individual States. Law was nothing more than the totality of the rules decreed by public authority with the purpose of establishing order within societies that were torn by such internal struggles. Law gave expression to the balance of power between the different elements of the society. The State itself was thus the expression of de facto power. ${ }^{12}$ This was possible only when the organisation of the State gave it the power to exercise constraint, because only by that means could order be maintained between the struggling groups. This also explained why law could only emerge from the strongest social grouping, because that group alone was capable of imposing its ideas of order on the rest of the society. This amounted, therefore, to saying that law was possible only within the context of the State. All law was based on the State, and there was no such thing as inter-State law. Obviously, therefore, international law was not law at all, since there was no coercive power higher than the State and capable of imposing norms of international law upon it. What was called 'international law' was no more than a collection of forms that were observed on a de facto basis by States and peoples engaged in peaceful relations. Gumplowicz emphasised these italicised words, because, he insisted, the outbreak of war put an end to all forms of 'intelligence and union'. The most he would accept was that circumstances had started to give rise to an 'international morality'; but to speak

12 G. Fassò, Storia della filosofia del diritto, vol. III, Bari, 2001, p. 161. 
of international law amounted to a category mistake. The rules of 'international law' thus remained outside the spheres both of law and of the State; they were merely a matter of history, in which the only principle governing the actions of States was egotism. In addition, under the influence of Darwinian evolutionism, Gumplowicz viewed with complacent confidence the element of selection characteristic of struggles of this kind. By reserving to history the last word on inter-State relations, on the basis of the 'law of the strongest', Gumplowicz's naturalist sociology reconnected with the idealist metaphysics of Lasson and Hegel. In the world of ideas, as elsewhere, there is a connection between the extremes.

True, Gumplowicz did not exclude the possibility that human societies might evolve in such a way as one day to leave this state of affairs behind them. Indeed, he specifically reproached Lasson for not taking that possibility into account. But, while reserving such possible developments for future times, Gumplowicz insisted that there was no way in which social science could sketch out the future march of events. It was already a considerable step even to admit the possibility of social developments that would enable a legal order to be established as between States. ${ }^{13}$

\section{Scandinavian Realism: Anders Vilhelm Lundstedt and Karl Olivecrona}

If Lasson was first and foremost a philosopher of law, and Gumplowicz a sociologist, A. V. Lundstedt and K. Olivecrona, by contrast, were 'pure' jurists, in the sense that their main concern was the study of positive law, especially private law. They approached problems concerning the general theory of law by abstracting from them - or at least that was their claim ${ }^{14}$ - all metaphysical elements. Their critical approach to juridical data was primarily concerned with issues of knowledge. Both were Swedes, disciples of Axel Hägerström (1868-1939), ${ }^{15}$ whose work had been a

13 For a more detailed exposé, cf. Walz, supra note $1, \S \S 9$ and 30.

14 In Hägerström's view one must eliminate metaphysics: praetera censeo metaphysicam esse delendam. See his work Die Philosophie der Gegenwart in Selbstdarstellungen, Leipzig, 1929.

15 On Hägerström and his school, cf. Fassò, supra note 12, pp. 289 et seq., with a bibliography at pp. 494-6. See also S. Verosta, 'Rezension von "Inquiries into the Nature of Law and Morals"”, ÖzöRV, vol. 6, 1954, pp. 448-51; Verdross, supra note 3, pp. 182-4; H. L. A. Hart, 'Scandinavian Realism', Cambridge Law Journal, vol. 17, 1959, pp. 233 et seq.; J. Pasmore, 'Axel Hägerström and his Disciples', in: G. Sawer (ed.), Studies in the Sociology of Law, Canberra, 1961; J. U. Lewis, 'Karl Olivecrona: Factual Realism and Reasons for Obeying a Law', University of British Columbia Law Review, vol. 5, 1970, pp. 281 et seq.; 
reaction against the idealist thinking then current in Sweden, and who professed a naturalistic positivism derived from Kant and accompanied by ethical relativism.

Anders Vilhelm Lundstedt (1882-1955) was Professor of Civil Law at the University of Uppsala and was the author of a major work published in German. Its title was symbolic: Die Unwissenschaftlichkeit der Rechtswissenschaft (two vols, Berlin, 1932, 1936), which might loosely be translated as 'The science of law is no science'. In this work he set out his general views, applying them particularly to civil and criminal law. A prior work, published in English, although altogether less weighty, is in fact more important for present purposes, because it particularly concerns international law. Its title was equally provocative: Superstition or Rationality in Action for Peace? (London, 1925). The two sub-titles were equally pungent: 'Arguments against the attempt to base global peace on a common sense of justice. Critique of the jurisprudence'. The title of a third work, this time in French, published at Brussels, was equally uncompromising: Le droit des gens, danger de mort pour les peuples (1937).

The two sub-titles to the English language work represented an entire programme. In effect, Lundstedt weighed the entirety of western legal science in the balance, and found it wanting. In his view, it was only a 'compacted metaphysical mass', crushed by the deadweight of fictions

G. McCormack, 'Scandinavian Realism', Juridical Review, vol. 15, 1970, pp. 33 et seq.; G. McCormack, 'Hägerström on Rights and Duties', Juridical Review, vol. 16, 1971, pp. 59 et seq.; H. H. Vogel, Der skandinavische Rechtsrealismus, Frankfurt-am-Main, 1972; E. Pattaro, Il realismo giuridico scandinavo, Axel Hägerström, vol. I, Bologne, 1974; W. Fikentscher, Methoden des Rechts, vol. II, Tübingen, 1975, Chapter 14, pp. 273 et seq. and 322-4; W. Ott, Der Rechtspositivismus. Kritische Würdigung auf der Grundlage eines juristischen Pragmatismus, Berlin, 1976, pp. 67 et seq. and 207 et seq.; N. E. Simmonds, 'The Legal Philosophy of Axel Hägerström', Juridical Review, vol. 21, 1976, pp. 210 et seq.; J. Bjarup, Skandinavischer Realismus: Hägerström, Lundstedt, Olivecrona, Ross, Munich, 1978; M. Dietz, 'Schwedische Rechtsphilosophie', Juristische Schulung, vol. 20, 1980, pp. 168 et seq.; J. W. Harris, Legal Philosophies, London, 1980, pp. 98 et seq.; L. L. Hierro, El realismo jurídico escandinavo, Una teoria empirista del derecho, Valencia, 1981; H. M. Pawlowski, Methodenlehre für Juristen, Heidelberg/Karlsruhe, 1981, pp. 130 et seq.; E. Pattaro (ed.), Contributi al realismo giuridico, Milan, 1982; H. L. A. Hart, Essays in Jurisprudence and Philosophy, Oxford, 1983, pp. 161 et seq.; C. Faralli, Diritto e magia, Il realismo di Hägerström ed il positivismo filosofico, Bologna, 1987. In a critical sense, cf. for example S. Jørgensen, Values in Law, Copenhagen, 1978, pp. 50 et seq., 156 et seq.; H. Coing, Rechtsphilosophie, 4th edn, Berlin/New York, 1985, pp. 63-4; pp. 59 et seq. (positivism); pp. 95 et seq. (critique). 
and fetishes that it could never throw off. Lundstedt, then, was an iconoclast, whose doctrine a Spanish commentator has called 'juridical nihilism'. ${ }^{16} \mathrm{He}$ was the most extreme representative of Scandinavian realism. Of course, we cannot explore his sometimes prolix arguments in detail here: suffice it to say, as a reference point from which we can seek to understand his position on international law, that for Lundstedt all legal realities depended on the existence of coercive power whose existence could be empirically verified in time and space. That power must then react against certain activities that were contrary to the general interest. The legal order was established and guaranteed by the habitual efficacy of this power, and by that alone: so-called 'subjective laws', 'legal duties', 'principles of justice' or other abstract and metaphysical concepts played no part. Such general concepts, far from being the foundation of the law, in fact presupposed its existence, and were consequences of the functioning of the organic State apparatus. They were no more than pure facts that could be empirically observed, not norms giving expression to deontological positions ('Thou shalt ... .'). In short terms, such 'facts' depended for their existence on effective sanctions by the courts and the executive. Law, then, was a fact sanctioned by another fact, a factual state of affairs factually sanctioned by the courts. In this way, Lundstedt believed it possible to completely eliminate the metaphysical element and fill all gaps with chains of empirically observable facts.

Obviously, no such coercive power existed at international level. The international community had no societal apparatus whose sure and regular functioning came into play, in specific situations, in order to protect that community's common interests. Internationally, the actions of States were motivated only by their own particular interests. There was no overarching organisation to provide regularly functioning legislative and judicial powers. It is the objective and regular functioning of coercive power that creates the community - not the other way round, the community creating the law. The League of Nations could have been the starting point for the establishment of an international community in Lundstedt's 'true' sense, but in his view was not such a starting point because, instead of serving the general interests of humanity, it turned itself into an instrument serving the national interests of the victor States of 1918. What was sometimes pompously referred to as the 'science of international law' was, at best, a juggling of fictions, and at worst a

16 L. Legaz y Lacambra, Introduccion à la ciencia del derecho, Barcelona, 1943, p. 137. 
hypocritical cloak for selfish national ambitions. It wallowed in the superstitious fantasy of States' 'subjective rights', designed only to justify the most brutal power-politics. In Lundstedt's view, the principle 'pacta sunt servanda' was a similar illusion. How could treaties be 'binding' without a coercive apparatus capable of enforcing them? He therefore reached a conclusion just as radical as Lasson's: so-called international law was merely an instrument of power politics. Finally, it should be noted that Lundstedt saw in the State nothing more than the collection of individuals composing it. He refused to recognise that the State had any kind of personality of its own. In that respect, he was poles apart from Lasson. ${ }^{17}$ The refusal to consider the State as a subject of the law also entailed a rejection of international law as an 'inter-State' law.

We find much of the same reasoning in Lundstedt's disciple, Karl Olivecrona (1897-1980), who was a Professor at the University of Lund. Olivecrona authored an English-language book published in 1939 under the title Law as Fact, with a German edition the following year, under the different and less expressive title Gesetz und Staat. The foundations of Olivecrona's ideas were analogous to those of Lundstedt, but he was noticeably more interested in questions of public law than Lundstedt had been.

As regards international law, Olivecrona started out no less radically than Lundstedt, though subsequently he did prise open the doorway to hope. For Olivecrona, a legal régime governing international relations was an impossibility, because the characteristic feature of any legal order was the State's monopoly control of the use of force within its territory. No such monopoly existed on the international plane. Certainly, one might speak of international law, in the sense of rules relating to inter-State relations, these being rules resulting from tradition, usage or treaties. Indeed, Olivecrona stressed the practical importance of such rules, without which international relations could not function. They owed their existence to imperious necessity. But they could not be called rules of law, because they were incapable of effectively directing and governing the conduct of those who, in each State, held the reins of power. Within a State, effective psychological motivations do operate, given that the political and social antennae of those in power impel them to use that power for the common good. At the international level, by contrast, political and social antennae operate in the opposite direction, impelling Governments to use force in the service of the national interest, not of the international community. Moreover, at the international level,

17 For more ample treatment, cf. Walz, supra note 1, §§ 11 and 31. 
the effective control of the use of force presupposes the establishment of firm and uniform psychological conditions amongst those who hold power. That in turn would require a solid organisation, capable of channelling the instincts of all the different countries and societies in the same direction. That could not be achieved in the current state of the international community. There was no remedy for the fact that States lived side by side without being bound by any shared law.

In these circumstances, Olivecrona could see only one alternative: either one allowed the existing inter-State lawlessness to continue, or one had to establish a supranational organisation capable of monopolising the use of force, which naturally would entail a curtailment of the existing 'absolute' sovereignty enjoyed by States. Admittedly, the world had been able to live, for better or for worse, with the prevailing system, under which international relations were not governed by law. But it was clear that technical progress would make this an ever more dangerous situation for the future of civilisation. Europe, in particular, must therefore opt for the second alternative, i.e., for the establishment of a solidly based super-State or federation. For all that, Olivecrona was well aware of the practical difficulties, but could see no other way out of the existing international anarchy. It was an illusion to suppose that the use of force could be controlled through treaties between the representatives of States as they stood. In other words, international law, properly so-called, was impossible in the very nature of things. The only possibility was the creation of public law applicable more or less universally, on a federal basis.

\section{US Neorealism: Percy E. Corbett, Hans J. Morgenthau and Others}

More recently, American (strictly speaking North American or US) realism followed up this line of thinking. ${ }^{18}$ As early as 1941, G. Niemeyer had denounced international law for its unreality. ${ }^{19}$ Percy E. Corbett and others denied the legal character of the phenomenon

18 On US legal realism, see G. A. Aichele, Legal Realism and TwentiethCentury American Jurisprudence, New York/London, 1990; M. Martin, Legal Realism, New York, 1997; J. H. Schlegel, American Legal Realism and Empirical Social Science, Chapel Hill/London, 1995; and also M. A. Rea-Frauchinger, Der amerikanische Rechtsrealismus, Karl L. Llewellyn, Jerome Frank, Underhill Moore, Berlin, 2006.

19 G. Niemeyer, Law Without Force: The Function of Politics in International Law, Princeton, 1941. 
'euphemistically' called 'international law': since the monopoly over the use of force was held by each particular State, what was called international law was, at best, only a system of law that might (perhaps) be in the process of gestation. The most radical position was surely that of Hans J. Morgenthau ${ }^{20}$ who argued that power was the axis of international life, and that international law, whose power and effects were insignificant, could not be expected to place any limitation on the play of power politics, which alone could produce diplomatic compromise - 'accommodation through diplomacy'. ${ }^{21}$ Morgenthau's work was widely read in the USA and elsewhere, and affected the thinking of many. George Kennan, a great diplomat who was sent to Moscow, shared much of the thinking of those cited above. ${ }^{22}$ In France, Raymond Aron defended similar theses with particular verve: his book Paix et guerre entre les nations (Paris, 1962) contained the following particularly striking sentence, even though he would subsequently consider it praiseworthy to work for the development of a stronger form of international law: '[International politics] have always been seen for what they are, namely the politics of power, by all concerned except for a few lawyers drunk on concepts, and a few idealists who confuse their dreams with reality' [our translation]. ${ }^{23}$ And indeed, one can also find traces of these views in the writings of professors of international law, even though they are usually more measured in the way they ascribe primacy to the power of force. ${ }^{24}$

It should be mentioned that this type of view has not disappeared. The US neo-conservatives and their lawyers continued to cling to this type of

20 H. J. Morgenthau, Politics Among Nations, 5th edn, New York, 1967. On Morgenthau and his influence, see also C. Hacke, 'Im Spannungsfeld von Macht und Moral, Zum 100. Geburtstag von Hans J. Morgenthau' in: Neue Zürcher Zeitung, no. 39, 17 February 2004, p. 5.

21 Even if, perhaps, at the very end of his life, Morgenthau came back on his initial positions giving some greater weight to international law: see F. A. Boyle, World Politics and International Law, Durham, 1985, pp. 16, 70 et seq.

22 G. F. Kennan, American Diplomacy, 1900-1950, Chicago, 1951. On these North American schools of thought, see J. L. Kunz, 'Der heutige Stand der Wissenschaft und des Unterrichts des Völkerrechts in den Vereinigten Staaten', ÖZöR(V), vol. 7, 1955-56, pp. 405 et seq.

23 R. Aron, Guerre et paix entre les nations, 8th edn, Paris, 1984, p. 691.

24 G. Schwarzenberger, Power Politics: A Study of World Society, 3rd edn, London, 1964. G. De Lacharrière, La politique juridique extérieure, Paris, 1983. 
conception of international law. This is the case mainly of the Harvard and Chicago lawyers J. Goldsmith and E. Posner. ${ }^{25}$ In their interesting monograph, they revert to the old idea that international law is not true law in the absence of mechanism of centralised sanctions. What remains is a normative order where States will heed their 'obligations' as long as they have an interest to do so; conversely, they will disobey international law once their interests are opposed to the fulfilment of the 'obligations' at stake. We may note in passing that this theory fits particularly well the policies of powerful States, which have a greater leeway in their choice of action than weaker States.

Most of the mentioned commentators were practitioners or diplomats who had worked in the Departments of Foreign Affairs of their respective States and for some had remained indelibly marked by the brutally opposing power politics of the Cold War. This hostile environment, with its competitive deafness, its threatening behaviour and unswerving enmity, made a decisive contribution to the ripening and development of the idea that power alone counts, and that anything else is little more than a smoke-screen. To this the conception has to be added that the respect of international law can be an instrument of weakness in the power competition between the 'free world' and the 'communist States'. It must finally be remembered that some of these diplomats were poorly versed in international law, often having only an approximate and reductive view of the subject.

\section{Critique}

There is no point in trying to minimise the importance of the views we have been considering. They cannot just be dogmatically rejected en bloc, disdainfully pushed aside as if there were no basis for them. Indeed, they are the more deserving of our attention given that they draw attention to real defects of current international life. And even when they go too far, they have unquestionably played an important part in inoculating the world against the superficial optimism that too readily accepts facile illusions. That power politics play an important role in world affairs cannot be denied by any bona fide observer.

25 J. L. Goldsmith/E. A. Posner, The Limits of International Law, Oxford, 2005. On this monograph and its central thesises, see H. J. Cremer, 'Völkerrecht - alles nur Rhetorik?', ZaöRV, vol. 67, 2007, pp. 267 et seq. See also A. Fichtelberg, Law at the Vanishing Point: A Philosophical Analysis of International Law, Aldershot, 2008. 
Generally speaking, the arguments presented are valid as descriptions of frequent irregular practices of States. It is as clear as anything can be that States often consider only their own selfish interests, and it is only too true that those seeking hegemonic power often dress up their conduct in legal phraseology purely for the protection of the positions they have and hold, or in order to acquire more. Nevertheless, to attempt to assess international life entirely and solely in light of such abuses is to go too far. Most States respect international legal constraints in most situations, especially weaker States with a rule of law tradition. This is also part of reality. The latter is much more multi-faceted than the stern sentence 'law $=$ power'.

Moreover, these commentators more or less openly treat law and force as synonyms. This, however, is unacceptable, confounding the is with the ought, the facts of the physical world with the concept of liberty. The essence of law cannot be understood by reference to the categories of the physical world, one of them being force. Law has its own autonomous categories. Admittedly, law rests on force, without which it cannot achieve the desired degree of efficacy. But it cannot be reduced simply to force. Indeed, force can be used in ways both legitimate and illegitimate, in the service of the law and against the law. The words of St. Augustine are highly relevant here: without justice, are States anything more than large-scale brigandry? Thus, so the argument goes, if we reduce law to force, a pirate with armed strength equal to Alexander's would be the latter's peer. ${ }^{26}$ Olof Hoijer's comment on natural law can be applied by analogy to all spheres of law: 'Force can, indubitably, be used against natural law, but cannot destroy it, because it cannot make that which is unjust just, nor vice-versa [...] Natural law is thus independent of force, and cannot be undermined by force, because it exists on altogether another, higher, plane' [our translation]. ${ }^{27}$ If one definitively identifies law with force, one forever abandons any idea of progress by the international community towards a juster world. And one abandons any idea that a conduct could be stigmatised as not being conform to a rule of the law. The least one can say is that one is thus deprived of a motivating force, an aspiration, of the sense of direction or of a benchmark that the norms of law and justice provide.

\footnotetext{
26 De civitate Dei, IV, 4.

27 O. Hoijer, Les traités internationaux, vol. I, Paris, 1928, p. 188.
} 
These doctrines also involve their authors, such as Lasson, in some axiological contradictions. Let us assume, for the sake of argument, that Lasson's profound idolisation of the State could be justified. If States are such superb cultural crucibles, how is it that they are unable to regulate their mutual relations except by purely mechanical means such as the use of force? Is there not a paradox in subjecting such pillars of morality to the blind interplay of forces? Is not the supposition that the purpose of culture is self-destruction a highly dubious one? No doubt the contradiction can be explained only in light of a belief in the salutary historical role of war. But experience shows this explanation of history to be unconvincing. The situation was described by Mr. Bourquin, with the poignant elegance of all his written work: '[War has become a cataclysm] which leaves only ruins, in which victors and vanquished, belligerents and neutrals, dispute among themselves in shared bankruptcy and anguish' [our translation]. ${ }^{28}$

As for Gumplowicz, Lundstedt and Olivecrona, they also make an identification between State law and law in general, their essential thesis being that outside the State there can be no law. This idea is shared by other authors, and indeed is an essential postulate of legal positivism. However centuries of legal theory bear witness to the opposite view. The postulate does, after all, amount to a claim that before States emerged there was no law: but how can any legal historian accept that? He is well aware that law long precedes the emergence of the constitutionally organised modern State, and thus long precedes organised constraint by the State. State law assuredly is a form of law, and indeed perhaps the most advanced form. But it is not the only garb in which the legal phenomenon can be dressed, and this is demonstrated by centuries of history.

Fundamentally, all these theories are a priori constructs of a strikingly dogmatic kind. This is particularly obvious in the case of Lasson, but the point applies equally to Gumplowicz, Lundstedt and Olivecrona. Despite the positivism they affect, they appeal to experience only to the extent that it falls within the framework of their preconceptions about the nature of law. Instead of asking themselves whether States do in fact submit to rules of conduct they consider legally binding, these authors proclaim that States cannot submit to such rules, for reasons of principle that each author explains in his own terms. Nevertheless, it is a demonstrable fact

28 M. Bourquin, 'Le problème de la sécurité internationale', CCHAIL, vol. 49, 1934-III, p. 475. 
that States do recognise the existence of such rules; that they consider them to be legal; that in general they observe those rules; and that they seek, when acting against those rules, to justify their conduct by reasoning which they seek to present as sufficient.

Olivecrona himself recognised the importance of a whole range of customs and treaties which, if States failed to comply with them, would make international life impossible. In his view, it was all the more important to respect and comply with them precisely because there was no overarching coercive mechanism to enforce them. The importance of such rules is due, above all, to the feeling that they are binding. As we have seen, of course there are many violations, but a rule does not cease to be a rule simply because it is violated. Indeed, it is in the very nature of every legal rule, as of every moral one, that it can be violated, because its purpose is to regulate the conduct of human persons, who are essentially free beings. Law belongs in the world of freedom, not to a world of necessity such as is governed by the laws of physics and chemistry. The mistake made by Gumplowicz, Lundstedt and Olivecrona is to fail to appreciate this difference, to consider law as a simple fact or a principle of action governed by causality. If it were so, legal rules would make no sense, since there is no need to regulate that which is necessary anyway. We do not need laws to tell us to digest what we have eaten, or that the moon must revolve around the Earth. And no legal rule can require the contrary, prohibiting digestion or the revolutions of the moon, because such a rule would be an impossibility. These examples demonstrate by their very absurdity that the laws of causality (simple facts) and normative laws (defining duties) do not operate on the same level. To treat them as the same impoverishes the phenomenon that is law, in a very considerable way, concealing or disregarding an essential part, indeed its most essential element. Law does not seek to describe realities: it seeks to transcend, in a given direction, each particular reality to which it applies, i.e., it seeks to direct realities. It cannot therefore be measured exclusively against these factual realities: it has to be measured against its own normative objectives, which are superior to mere facts. Those objectives belong to the sphere of legal and social values. Law is therefore more than a fact, and more than the fact of power or force. 


\section{B. DOCTRINES REDUCING INTERNATIONAL LAW TO INTERNATIONAL MORALITY OR TO INTERNATIONAL COMITY ('COMITAS GENTIUM’)}

If the theories we have so far been considering flatly deny the existence of any legal principle applicable to international life, those we will consider next are less radical in nature. They do not dispute the existence of binding rules of conduct in the field of international relations, but merely refuse to recognise in them the character of rules of law. For some of these commentators such rules are a matter of 'international morality' or even 'international courtesy'. For others they are a sui generis ordering of affairs, a system separate from law itself. Either way, here the problem is presented as, above all, one relating to the technical delimitation of the rules regulating international relations. Underlying these doctrines is a conception of the law generated exclusively in terms of modern State law. Having recognised that this conception does not apply to the rules governing inter-State relations, these theories simply exclude such rules from the category 'law'; but they do not necessarily give up the idea of the bindingness of these rules. Thus, there is here no equation 'law / binding rules = power'. A considerable number of commentators have subscribed to views of this kind, though some are more rigorous about it than others. As one would expect, they frequently repeat arguments that in essence are the same. So we will concentrate on the most characteristic theories, and on those whose influence has been particularly long-lasting.

One might plausibly argue that the reduction of international law to a matter of 'international morality' has enjoyed a particular vogue among English theorists. Their great precursor was none other than Thomas Hobbes himself. ${ }^{29}$ In his celebrated Elementa philosophica de cive (1642) and Leviathan (1651), Hobbes argued that law required the security of reciprocity, and that such security could be guaranteed only by centralised and absolute power. Such power had been established, in political society, by means of a social contract in which individuals renounced the

29 Cf. Walz, supra note 1, pp. 7 et seq. On the doctrine of Hobbes, cf. M. Malherbe, 'Hobbes', in: P. Raynaud and S. Rials (eds), Dictionnaire de philosophie politique, Paris, 1996, pp. 320 et seq.; R. Polin, Politique et philosophie chez Thomas Hobbes, Paris, 1953; L. Strauss, The Political Philosophy of Hobbes, 3rd edn, Chicago/London, 1963; N. Bobbio, Hobbes and the Natural Law Tradition, Chicago, 1993. Fassò, supra note 12, vol. II, pp. 109 et seq., with a complete bibliography at pp. 350-51, 386-90. See also Verdross, supra note 3 , pp. 105 et seq. 
primitive liberties they were privileged to enjoy in their original state of nature. But nations, for their part, are still living in a state of nature, there being no superior power that can limit or control them. They enjoy no guarantees of security, because there is no superior authority, no superLeviathan. One cannot therefore say that any kind of law applies between them. Consequently they are not, and cannot be, burdened with anything more than merely moral obligations. This position was taken up and developed further by a series of lawyers.

\section{John Austin and the British 'Analytical' School}

The vogue in Great Britain, and under British influence the USA, enjoyed by the reduction of the law of nations to nothing more than moral obligations was owed, above all, to a great jurist, John Austin (1790-1859). Although Austin's floreat was in the first half of the nineteenth century, produced in the course of a series of lectures some of which he published in 1832, his influence really made itself felt in the last third of the century, after 1869, in which year his widow posthumously published his collected lectures under the title Lectures on Jurisprudence or the Philosophy of Positive Law. This highly important work was translated into French in 1894, and a series of re-issues indicate the importance of Austin's work in moulding contemporary British legal thinking. His role is the more remarkable given that his doctrine, as Professor Walz has emphasised, ${ }^{30}$ hardly seems well adapted to English traditions of jurisprudence, as encapsulated in the common law and the case law which sustains it. On the contrary, Austin's work rather inclines towards the more legalistic and formalistic continental approach, with which he was very familiar. If, at first sight, his influence seems to us a little disconcerting, it can doubtless be explained by the clarity with which he expressed himself and the rigour of his methods.

Austin's theory started with the study of law. He observed that law is essentially a command emanating from a higher authority. Of course, not every such command amounts to a law: it is only law if, not being - for example - a merely arbitrary ad hoc affair, it has the characteristics of stability and generality that are capable of making it obligatory and binding upon a group of individuals. But the word 'law' was not always used with the same degree of rigour: there were in fact various categories. First of all, there were 'the laws proper or properly so called'. This category comprised on the one hand divine laws, whether

30 Cf. Walz, ibid., p. 57. 
revealed or not (the latter being natural law), and on the other hand positive juridical laws. Then there were laws in the wider sense - 'the laws improper or improperly so called'. These were 'laws' only by analogy, and in this category were positive moral laws and laws in the derivative sense of the word, first and foremost the laws of physics. The categories of greatest interest for Austin's purposes were positive laws, both juridical and moral. Positive juridical laws were characterised by the facts that they emanated from a pre-determined person being endowed with reason, or from a pre-determined assembly similarly endowed with reason, that they implied a relationship of subordination, and that they involved the possibility of their being implemented or enforced through the application of constraint. This possibility of course presupposed the existence of appropriate organs to do the job. In short, positive juridical law was conceivable only in the context of an organised State.

On this basis, it is clear that the 'law of nations' could not truly be considered law. In Austin's view, its rules were not juridical in nature, not laws properly so-called, but instead were positive moral laws. They did not emanate from pre-determined individuals or assemblies, but from the more or less diffuse opinions of the international community. They also lacked the imperative character of true laws. They were in fact analogous to the rules of honour, of conduct, and of courtesy. But Austin insisted that they were positive moral laws, because they applied in the world of fact. They were not, in other words, ideal rules laying down what ought to happen so as to constitute a body of ethics. Quite the contrary, these were rules that existed, in the sense that they were observable in the real world. In light of this distinction, and in order to be completely precise, these rules should be categorised rather as rules of courtesy, given that they did not imply, as moral rules do, the making of a value-judgment, and translated simply into the realities of conduct among statesmen operating in the international context. Austin therefore asserted that international law was positive in nature, while at the same time denying that it was truly legal in character. It was thus reduced to positive morals, and in fact to the realm of courtesy. ${ }^{31}$

31 For a more elaborate examination, cf. Walz, ibid., pp. 56 et seq. and 184 et seq. On Austin's legal doctrine generally, and on his influence, cf. W. J. Brown, The Austinian Theories of Law, London, 1906; E. Roguin, La science juridique pure, Paris/Lausanne, 1923, pp. 3-55; F. J. C. Hearnshaw, 'John Austin and the Analytical Jurists', in: F. J. C. Hearnshaw (ed.), The Social and Political Ideas of Some Representative Thinkers of the Age of Reaction and Reconstruction, New York, 1949, pp. 158 et seq.; F. Gonzalez Vicen, 'El positivismo en la filosofía del 
Austin did not exclude the possibility that some of this "positive morality' might eventually be transformed into true law, if, for example, a State or its tribunals were to adopt it and enforce it by appropriate sanctions. But it would then be State law concerned with international relations, and as such would not differ in its essential kind from other State law. To use an expression also employed by other authors, these rules would then simply amount to 'external State law': they would not be international law in the true sense of the term.

We have already noted that this doctrine, as indeed that of Hobbes, sits uneasily with English legal traditions. In those traditions, law in large measure comes up from below, thanks to the creative role of case law, which Austin would have, of necessity, to see as making its contribution by way of a kind of delegation. His doctrine has, however, been closely followed within the analytical school of jurisprudence in both the UK and the USA, in which countries a whole series of authors have drawn on his fundamental ideas. So far as concerns international law, it suffices to mention I. R. Stephen (International Law and International Relations, London, 1884), John Norton Pomeroy (Lectures on International Law in Time of Peace, Boston and New York, 1886), F. E. Smith (International Law, London, 1900), and above all the masterly Scottish commentator on international law, James Lorimer (1818-90) in his Institutes of the Law of Nations (2 vols., 1883-84).

\section{Julius Binder (First Position)}

If the reduction of the law of nations to international morality or courtesy enjoyed the vogue in the UK that we have been considering above, it also had its defenders on the European continent. The available precedents

derecho contemporánea', Revista de Estudios Políticos, vol. 21, 1950, pp. 51 et seq. See also Verdross, supra note 3, pp. 175-6; A. Agnelli, J. Austin alle origini del positivismo giuridico, Turin, 1959; M. A. Cattaneo, Il positivismo giuridico inglese: Hobbes, Bentham, Austin, Milan, 1962; A. Truyol y Serra, 'John Austin et la philosophie du droit', Archives de philosophie du droit, vol. 15, 1970, pp. 151 et seq.; W. Löwenhaupt, Politischer Utilitarismus und bürgerliches Rechtsdenken. John Austin und die Philosophie des positiven Rechts, Berlin, 1972; G. Maher, 'Analytical Philosophy and Austin's Philosophy of Law', Archives de philosophie du droit, vol. 23, 1978, pp. 401 et seq.; W. L. Morison, John Austin, London, 1982; W. Rumble, The Thought of John Austin, London, 1985; R. Sèvre, 'La théorie du droit de John Austin: le positivisme tel qu'il devrait être?', in: S. Goyard-Fabre (ed.), Du positivisme juridique, Caen, 1988, pp. 69 et seq.; N. Bobbio, Il positivismo giuridico, Turin, 1996, pp. 96 et seq.; G. Fassò, supra note 12, vol. III, pp. 32 et seq. 
there may have been less striking, but they were not lacking. In Germany, for example, there was the great pandectist Georg Friedrich Puchta; in France, at a more modest level, there was Gérard de Rayneval and his Institutions du droit de la nature et des gens (1803). In the period we are considering here, the most developed and systematic work in this direction was done by the German neo-Hegelian philosopher of law Julius Binder (1870-1939), ${ }^{32}$ who taught at the University of Göttingen from 1919 until his death 20 years later. His earlier ideas were presented in their most developed form in his great work Philosophie des Rechts, published in 1925. Since his earlier thinking subsequently evolved further, there is a temptation to leave it to one side. But his references, sometimes embryonic, to ideas that are still in circulation, is a reason not to do so.

In Binder's writings, Hegel's philosophy again made its influence felt in relation to international law. However for Binder, Hegel was, so to speak, the point of arrival, not the point of departure. Binder's thought, at first oriented towards Kant, subsequently changed direction under the influence of first Fichte, then Hegel, so that Binder ended by becoming one of the most orthodox of Hegel's contemporary disciplines. It is curious to observe in Binder, at the individual level, the same development that, in the broad stream of German idealism, had led from Kantian criticism to Hegel's objective idealism, via the subjective idealism of Fichte and Schelling's philosophy of identity. But when Binder was writing his Philosophie des Rechts, this development was still at least partly in the future, which explains why Binder, even though basing himself on Hegel, was not in complete agreement with him.

Binder saw law as the ethical ordering of a community. But the community itself was not to be understood from the point of view of the individuals composing it, as individualists did, because it had its own reality, again just as individuals did. Indeed, the community was even more real than the individual, because it was, so to speak, the condition for the individual's personality. The community was the form under which objective reason manifested itself. Far from taking its value from individuals, the community had a value of its own. The life of the individual made sense only as a function of the community. For it was in the form of peoples or nations that objective reason, which made culture possible, was 'individualised' in history. Here we are in the presence of a

32 On Binder, see: Walz, ibid., pp. 79 et seq.; 204 et seq.; Fassò, ibid., pp. 224-5. 
trans-personalist conception of law, a version of which we have already seen in Lasson.

On the basis of this trans-personalist conception, the question as to the legal nature of international law comes back to that of the existence of a supranational community for which it would provide the ethical ordering. The response, for Binder, was never in doubt: no such community existed. Not only that - even its existence was an impossibility. The various nations and peoples had their reality solely as individual forms of the objective spirit; humanity itself was only an abstraction. The individual was conscious only of his personality and nationality. There was therefore no international law, because there was no international community. If Binder is to believed, the rules designated as international ones are either moral rules (if they depend on ethics and conscience), or matters of international usage (if they rest exclusively on the constant practice of States).

Where there was no feeling of allegiance, and no effective community discipline, there could not be law. That, in short, was Binder's conclusion. These passages in Binder come close to the thinking of one of the most eminent international lawyers, Charles de Visscher, who identifies the same absence amongst individuals of any universal sense of community, although he does not draw the same conclusions as to the existence of an international legal order:

Within the State, it is vital interests, the most political of all, which give rise to the highest feelings of solidarity. For the international community, the opposite is the case. There, we find only minor elements of solidarity, for example in the economic or technical fields; but the closer one gets to vital questions, such as peace and war, the less the international community's actions impinge on its members; the elements of solidarity become more feeble in inverse proportion to the growth of threats and perils, and sentiment then flows back towards its traditional 'home', in the nation. In exercising its powers of reasoning, humanity can hardly be said to actually dispute the existence of supranational values: but when it comes to action, imperatives of an almost exclusively national character rule the roost [our translation]. ${ }^{33}$

33 Ch. de Visscher, Théories et réalités en droit international public, 4th edn, Paris, 1970, p. 112. A more radical attitude is found in the French student of politics Georges Burdeau, who emphasised the still embryonic character of international law in light of the apparently limited attractions of collective international interests: '[It] is not excessively pessimistic', he wote, 'to observe that it is rare for a State to be blinded by its concern for the common international good' [our translation]: Traité de science politique, vol. I, Le pouvoir politique, Paris, 1959, p. 367. For Burdeau, the existence of the State was the only obstacle to the establishment of a body of international law worthy 
Or, in the words of M. Bourquin:

We can hope that the day will come when the idea of their common interests will have as powerful an influence on the peoples of the world as the mystiques of their various national identities, and that they will see the idea of the common international interest as justifying the same kinds of sacrifices as nations expect of their citizens. But we do have to accept that the world is a long way from any such sense of its common humanity [our translation]. ${ }^{34}$

To those objecting that morality is necessarily a matter for the individual conscience, Binder's response was to argue that, from the point of view of reason operating objectively in history through the nations, it was pointless to refer morality to individuals. The State, as an individual human community living under a legal order of its own, was subject to the moral law. Statesmen must respect the moral law in their public as in their private activities. The only difference was this, that the concrete precepts of public morality and private morality might be different. ${ }^{35}$

\section{DOCTRINES CONSIDERING THE LAW OF NATIONS TO BE A SUI GENERIS COLLECTION OF RULES}

If Austin and Binder reduced the law of nations to the 'morality of nations' or 'international courtesy', Felix Somló (1873-1920) ${ }^{36}$ regarded it as a sui generis category of rules.

This Hungarian jurist, a man of vigorous cast of mind, was born in 1873, and became a Professor at the University of Budapest before coming, in 1920, to a tragic end while still in his prime. A positivist who ended up a neo-Kantian, Somló developed his theory of international law in the context of a general theory of law. His Juristische Grundlehre,

of the name. Current international law was, in his view, only State law for external purposes, a prolongation of internal law for the purpose of facilitating reciprocal inter-State relations in certain fields. An international legal order was a necessity, and it was therefore necessary to work for the creation of a supranational global power. He concluded as follows: 'It is mankind's consciousness of its common destiny that will give force and energy to a Power that is disentangled from national servitudes.' [our translation]: ibid., p. 391).

34 Bourquin, supra note 28, p. 521.

35 For a more ample exposition of this phase in the development of Binder's thought, cf. Walz, supra note $1, \S \S 16$ and 39.

36 On F. Somló, see: Walz, ibid., pp. 70 et seq. 
published in 1916, with a second edition in 1927, provided, in the words of Professor Giorgio del Vecchio, 'one of the finest critical analyses of fundamental legal concepts' [our translation]. ${ }^{37}$

Felix Somló shared more than one point of view with Austin, and never concealed the influence on him of that great founder of analytical jurisprudence. His definition of law calls to mind that of Austin, in the decisive importance it gives to the imperative element. According to Somló, law was a collection of norms established by a supreme, permanent and extensive power that is commonly obeyed. Rules of law could exist only where a supreme power held sway over a group (whether large or small) of individuals, and where that power's orders were generally obeyed. This criterion of habitual obedience obviously could not be absolute in its scope. It was an approximation: it sufficed if the rules of conduct decreed by the supreme power were respected in most cases. As to the extent of the supreme power's authority, it was not enough for it to establish various sporadic and isolated rules. An isolated rule of law was not, as such, a concept that makes sense. It made sense only in the context of an ensemble embracing the widest possible aspects of the life of the society concerned.

Applying this definition of law to the international plane, the inevitable conclusion was that a law of nations did not exist, because the essential conditions for the existence of a legal order, as defined by Somló, were lacking. So far as supreme power was concerned, Somló did not for a moment deny that the rules of so-called international law emanated from a power superior to the individual States. But this power, in relation to which the great Powers played a decisive role, was too unstable to qualify as a juridical one. It was reduced to nothingness whenever there was a serious dispute between the principal States, such as a war. Furthermore, many of the rules it established had only limited validity, because the outbreak of war simply put an end to them. In addition to this want of permanence in the international power, was the fact that the legal order it created was a poor and feeble one. There were not many rules, and they did not amount to the overall regulation of inter-State relations. In fact they dealt only with more or less secondary aspects of international life. This systemic weakness was, for Somló, the main reason to deny that they were in any way legal in nature. But there was yet another reason propelling him in the same direction: even though they were not very numerous, the rules of so-called international law were

37 Filosofía del derecho, Spanish translation, 3rd edn, revised by L. Legaz y Lacambra, Barcelona, 1942, p. 239. 
complied with in a very irregular and imperfect way. They did not reach the minimum threshold of application which, as we have seen, was required by Somló's definition of law.

One might, at a pinch, admit that Somló's argument was well-founded as regards 'common' international law, and yet wonder whether at least 'particular' international law, based on treaties, can be said truly to exist. Somló's response was that a treaty was not, in itself, a legal phenomenon. It became one only by virtue of a pre-existing legal norm. This was not to deny that treaties are binding, as indeed they were, but always by virtue of a general norm such as pacta sunt servanda. They were binding also for other non-legal reasons, such as, for example, the dictates of ethics. But that was not a matter of law.

Having presented such a closely argued concept of law and of the possibility of laws being the principal regulator of international life, the natural question is as to what, in Somló's view, was the nature of the rules of international law (for he did accept the existence of what were called rules). If they were not truly rules of law, what were they? Somló denied them the character of moral norms, on the grounds that, while morality was autonomous and absolute, such rules were heteronomous, and were content to provide no more than a relative measure of justice. He therefore considered it more exact to call them conventional matters of agreement, or rules of courtesy. This was Somló's interpretation of Austin's expression 'positive morality'. In Somló's view, however, it was preferable to think of them as a species of heteronomous rules of conduct. So he proposed simply to call them international or supranational norms, ${ }^{38}$ in this way reflecting the power that generated them.

\section{CRITICAL CONSIDERATIONS REGARDING THE LAST TWO GROUPS OF DOCTRINES}

\section{International Law as a Different Type from State Law}

All these doctrines took, as the basis for their definition of law, the law of the modern State. At bottom, the reproach they levelled at international law was that it was not like internal State law. Obviously, however, international law cannot, by definition, be the same as internal State law. These doctrines took as their inductive basis their definition of State

38 For a more elaborate examination, cf. Walz, supra note 1, §§ 14 and 37; Gonzalez Vicen, supra note 31, pp. 62-7. 
law as developed in western societies in the nineteenth and twentieth centuries, namely in a relatively stable context. It has to be said that this basis is too narrow, precisely because it is, in the last resort, focused on one particular historic mode of law, linked to a particular region and cultures. Such a basis cannot be hypostasised into an a priori definition of all law in all places. Historically, law can present itself in other forms, and has in fact done so. We can therefore say that the doctrines in question erred by excessive dogmatism about the phenomenon that is law. They are all based on some a priori definition of the law, against which the concrete 'legal' phenomena are then measured. In this regard such doctrines are anti-historical, flying in the face of experience. The existence of law long precedes the emergence of the modern constitutionally organised State. State law is a form of law, perhaps indeed the most developed form (an axiological conception). But it is not the only garb in which the legal phenomenon can appear. Neither natural nor canon law, for example, can be conceived of in a satisfactory way by those who reduce all law to the measure of modern State law.

International law exists for the purpose of regulating a communal environment very different from that governed by modern State law. It must be judged ${ }^{39}$ by its suitability to discharge effectively the functions appropriate to its own social environment, which is primarily an interState one, although there are growing elements of interpenetration between the international and internal levels. ${ }^{40}$ One must then ask whether international law in actual fact does or does not adequately discharge the function of delimiting competences and the various aspects of co-existence and co-operation between States as sovereign entities, and whether it allows other subjects of law to exercise their rights and discharge their obligations in a useful manner. In forming an assessment of this question, one has to take account of the fact that international law governs a community of legal equals, one containing no regular superior power. ${ }^{41}$ In this respect it bears a resemblance to legal orders in pre-State

39 Cf. P. Weil, 'Le droit international en quête de son identité, Cours général de droit international public', CCHAIL, vol. 237, 1992-VI, p. 55.

40 See the fine study by O. Dörr entitled 'Privatisierung' des Völkerrechts', Juristenzeitung, vol. 60, 2005, pp. 905 et seq.

41 Otherwise, it would be rather like comparing the efficacy of the United Nations to that of the Swiss federal administration. These are not like cases. The UN administration has no executive powers and no power to take decisions. It proposes, but cannot dispose. The UN is not a super-State, but a centre for the co-ordination of the efforts of independent sovereign entities. If the States of the world wanted to make it 'truly effective' in the sense that the man in the street 
times, which historically have been numerous. Viewed in this light, the arguments advanced by the authors in question lose much of their value.

\section{The Absence of any Power Superior to States}

A frequently repeated argument related to the absence of any power superior to the States and capable of legislating and executing its decisions, and also to the lack of any compulsory jurisdiction. This argument failed to recognise that law as we know it today is a relative late-comer in the development of legal conceptions. In the early stages of every society, it was custom which provided the basis for orderly human relations. And in fact custom continues to play an important part even in the most advanced stages of legal life, alongside law properly so-called. This can be seen in particular in the context of constitutional law. Even outside the realm of custom, positive law can be created without having a centrally sanctioned character: this was notably true in feudal law, which in large measure was constituted by a series of pacts between lords and their vassals. Still today, significant parts of constitutional law cannot be sanctioned by some legal process. What was true of law-making was also true of the activities of judges. The establishment of courts with compulsory jurisdiction followed an era of self-defence, and of forms of arbitration freely agreed between the parties. It was the growing complexity in the life of the community which made necessary the existence of legislators and judges. Finally, States came to accept international law as a reality, one to whose evolution they themselves had contributed. They made treaties, they argued their legal cases, they created legal departments, they pleaded their cases before tribunals, they sought legal opinions, and so on. How then could it be said that all these realities bit on nothing because there was no law? It was to say the least surprising that this stance was nevertheless adopted by doctrines vaunting themselves on their 'realism'.

It perhaps remains to be seen whether in international law the kind of evolution as was witnessed in municipal societies is under way. Legislation at international level is not completely lacking, as can be seen from the agreements we might categorise as multilateral normative treaties, or simple treaty laws. Nor is there a complete lack of jurisdiction in the field of international relations, especially since the creation of the Permanent Court of International Justice, now the International Court of

would mean by that expression, they would have to give up their sovereignty and endow the UN with powers to execute its decisions and to raise taxes. 
Justice. As for arbitration, the mechanism is an extremely ancient one: in times past it enjoyed exceptional favour within Christendom, under the auspices of the Church. Today, arbitration is a very common feature in international affairs, in almost all legal fields of international law: general inter-State law, investment litigation, WTO-litigation, etc. What is true, however, is that these forms for deciding and applying law were and are much less well developed at international level as compared with the national. Also, in order to function, they presuppose, except in the cases of certain international organisations such as the European Union, that States consent to them. Nevertheless, these considerations should not lead us to the further conclusion that the law of nations is somehow a defective system of law as compared with State law. The difference between the two is intrinsically quantitative rather than qualitative. And the notion of 'defect' would imply that as long as international law has not become exactly as is its municipal counterpart (a thing that it cannot anyway achieve), it is not functioning correctly in its own legal and social environment. But that would be a wrong conclusion: international law is not shaped in order to function as municipal law; if it were, the States would have to relinquish their sovereignty. This is not what States seek.

\section{The Absence of Sanctions and Constraints}

Most of the doctrines we have just been considering took account of the lack of any international mechanism of coercion or constraint to support the relevant norms. In this connection, the first thing to note is that a large number of authors do not consider constraint an essential element of the notion of law. ${ }^{42}$ Moreover, elements of constraint do exist in international law, in various forms, running from the simple withdrawal of diplomatic representation to reprisals and possibly even the resort to war. Reprisals and formerly war are often considered the most important sanctions available in support of international law. ${ }^{43}$ It is true that, as a

42 There are even certain authors who consider law unaccompanied by constraint the archetype of the most developed law, based on consent rather than the point of the sword: cf. R. Marcic, Rechtsphilosophie, Freiburg-im-Breisgau, 1969, pp. 214 et seq., 218. More generally, see Weil, supra note 39, pp. 53-4.

43 H. Kelsen, Reine Rechtslehre, Leipzig/Vienna, 1934, p. 131:

[D] as Völkerrecht ist noch eine primitive Rechtsordnung. Es steht erst am Anfang einer Entwicklung, die die einzelstaatliche Rechtsordnung bereits zurückgelegt hat. Es zeigt zumindest im Bereich des allgemeinen Völkerrechts und sohin für die ganze Völkerrechtsgemeinschaft noch weitgehende Dezentralisation. Es gibt hier noch keine arbeitsteilig funktionierenden 
form of private justice, war is nowadays forbidden by the rules of international law - particularly Article 2, $\$ 4$, of the United Nations Charter. In its stead, the competences of the Security Council sometimes supply the organised international community with legally stronger means of sanctioning the most serious breaches of international legality. Decentralised 'sanctions', especially reprisals, have three fundamental disadvantages. The first is that there is often a disproportionate relationship between the rights to be protected and the means necessary to protect them. The second is that success depends on the balance of forces in the particular theatre. The third is that reprisals are based on purely subjective claims as to an internationally unlawful act and are thus an 'anarchical' device of law-enforcement. The result is that reprisals often lead to an increase rather than a reduction in violence and injustice. This is plainly a weakness which will need to be addressed if the international community truly wishes to establish order and justice between the peoples of the world. But it cannot be said that international law lacks a form of 'sanction' - albeit a peculiar one.

\section{The Absence of an International Community}

Had Binder's argument that no real international community actually existed been well-founded, it would have been much more powerful than his argument about the absence of sanctions. Binder rightly associated the idea of law with the concept of community, and in doing so was following the old Roman adage ubi societas, ibi jus. In truth, however, his conclusion begged the question, for instead of calmly considering the international realities in order to see whether a community of peoples existed, Binder, like Lasson, dogmatically proclaimed the very idea to be impossible. And why? Because the objective spirit was an individual matter and could be individualised only in the various nations. Like

Organe zur Erzeugung und Vollziehung der Rechtsnormen. Die Bildung der generellen Normen erfolgt im Wege der Gewohnheit oder durch Vertrag, das bedeutet: durch die Glieder der Rechtsgemeinschaft selbst und nicht durch ein besonderes Gesetzgebungsorgan. Und ebenso auch die Anwendung der generellen Normen auf den konkreten Fall. Es ist der sich in seinen Interessen verletzt glaubende Staat, der sich selbst zu entscheiden hat, ob der Tatbestand eines Unrechts vorliegt, für den ein anderer Staat verantwortlich ist. Und wenn dieser das behauptete Unrecht leugnet, fehlt es an einer objektiven Instanz, die den Streit in einem rechtlich geregelten Verfahren zu entscheiden hat. Und so ist es auch der in seinem Recht verletzte Staat selbst, der gegen den Rechtsverletzer mit dem vom allgemeinen Völkerrecht eingesetzten Zwangsakt, mit Repressalie oder Krieg, zu reagieren befugt ist. 
Lasson, Binder was projecting his pantheistic metaphysic of the State onto the international plane, doing violence to the realities in order to take them captive. Admittedly, Binder did not go as far as Lasson, because he did subject the State to the moral law. Nevertheless, if the State's submission to moral imperatives was compatible with its metaphysical dignity, it is very difficult to understand why its submission to a legal order should be any the less compatible. The very idea of a plurality of nations representing different but equally justified facets of the richly diverse universal spirit, ought to have brought both Binder and Lasson to postulate the existence between States of cultural relationships subject to the rule of law. This was, moreover, what Hegel had done, and indeed Binder was ultimately to embrace the idea in his last great work, although the foundation of inter-State law he would then identify was, as we shall see, to be an inadequate one.

Independently of Hegelian and neo-Hegelian theories, we can thus see that the different degree of integration and cohesion of the international community, as compared with nations internally, is a quantitative difference, and that its importance depends on the historic moment at which one makes the assessment. Elements of solidarity are not lacking in the international community, particularly at regional and functional levels. In the last part of the twentieth century, elements of a more integrated international community co-exist with traditional national interest policies. ${ }^{44}$

44 On this international community, cf. E. Jouannet, 'La communauté internationale vue par les juristes', Annuaire français des relations internationales, vol. 6, 2005, pp. 3 et seq. See also M. Giuliano, La comunità internazionale e il diritto, Padua, 1950; G. Vedovato, La Comunità internazionale, Florence, 1950; G. Maturi, Il problema giuridico della Comunità internazionale, Milan, 1956; A. Migliazza, Il fenomeno dell'organizzazione e la Comunità internazionale, Milan, 1958; L. Legaz y Lacambra, 'Völkerrechtsgemeinschaft, Ideologie, Utopie und Wirklichkeit', Essays in Honor of C. Schmitt, Berlin, 1959 (reprinted in 1989), pp. 123 et seq.; De Visscher, supra note 33, pp. 110 et seq.; H. Mosler, 'The International Society as a Legal Community', CCHAIL, vol. 140, 1974-IV, pp. 17 et seq.; R. J. Dupuy, 'Communauté internationale et disparités de développement, Cours général', CCHAIL, vol. 165, 1979-IV, pp. 1 et seq.; H. Mosler, 'International Legal Community', EPIL, vol. 7 (1982), pp. 309 et seq.; A. Truyol y Serra, 'Cours général de droit international public', CCHAIL, vol. 173, 1981-IV, pp. 53 et seq.; R. J. Dupuy, La Communauté internationale entre le mythe et l'histoire, Paris, 1986; M. Lachs, 'Quelques réflexions sur la Communauté internationale', Essays in Honor of M. Virally, Paris, 1991, pp. 349 et seq.; P. M. Dupuy, 'Humanité, Communauté et efficacité du droit', Essays in Honor of R.J. Dupuy, Paris, 1991, pp. 133 et seq.; G. Abi-Saab, "Humanité" et "Communauté" dans l'évolution de la doctrine et de la pratique du droit international', 
Of course the modern State is an incomparably more solid structure than the international community. Nationalism, which, since the decline of the mediaeval respublica christiana has enjoyed an ever-increasing vogue despite the efforts of the humanists and the eighteenth century thinkers, has had the unfortunate effect of rolling back, in the consciences of too many of the people of our times, the feeling that they belong to the universal community of the human race, of which each State is no more than one member. Conversely, all too often nationalism has been opposed by an internationalism that is too cosmopolitan and too superficial, holding cheap peoples' natural attachment to their national cultures: this kind of internationalism inevitably collapses with the coming of any great historical crisis. Some form of international community does truly exist, although at a lesser level of spiritual and emotional integration than State communities. Action on its behalf is taken, for instance in the context of climate change. To recognise the existence of this international community is in no sense to degrade national cultures in the interests of a cultural uniformity which is perhaps, through technological advance, one of the gravest dangers facing humanity. One has also to give a nuanced treatment to the contrasts between the international community's degree of spiritual and emotional integration and that of State communities, because in certain given circumstances a State's integration and cohesion can decline, for example in a civil war, or in failed States, or where there are conscientious objectors, or whenever someone professes a universal religious or philosophical belief that sets some limits to national loyalty.

Essays in Honor of R. J. Dupuy, Paris, 1991, pp. 1 et seq.; G. Herczegh, 'The International Community of States', Questions of International Law, (Budapest), vol. 5, 1991, pp. 75 et seq.; G. C. McGhee, International Community: A Goal for a New World Order, Lanham, 1992. G. Abi-Saab, 'International Law and the International Community: the Long Road to Universality', Essays in Honor of W. Tieya, Dordrecht/Boston, 1994, pp. 31 et seq.; C. Tomuschat, 'Die internationale Gemeinschaft', Archiv des Völkerrechts, vol. 33, 1995, pp. 1 et seq.; G. Abi-Saab, 'Whither the International Community?', EJIL, vol. 9, 1998, pp. 248 et seq.; B. Simma and A. Paulus, 'The International Community: Facing the Challenge of Globalization', EJIL, vol. 9, 1998, pp. 266 et seq.; P. Moreau Defarges, La communauté internationale, Paris, 2000; D. Kritsiotis, 'Imagining the International Community', EJIL, vol. 13, 2001, pp. 961 et seq.;. A. Paulus, Die internationale Gemeinschaft im Völkerrecht, Munich, 2001; P. M. Dupuy, 'Cours général de droit international public: l'unité de l'ordre juridique international', CCHAIL, vol. 297, 2002, pp. 245 et seq.; etc. 


\section{International Law's Want of Practical Efficacy}

As a general observation, it does have to be said that people are very often far keener to emphasise the failings of international law than they are to recognise its achievements. At the end of the day, the great majority of international treaties are complied with, and in any event, States do not enter into them lightly, but have to take account of the fact that their treaty obligations will condition their subsequent conduct. The effects of breaches of international law, and the scale of many of their consequences, are no doubt the reason why so much attention is lavished on them. At the root of doubt about the efficacy of international law, we find a rather glib association of decentralisation with want of efficacy. The unexpressed but nevertheless often present supposition is that nothing can be effective unless there are constraints to enforce it: without constraints, the thing will necessarily fail to be effective. If, in the ultimate analysis, it is not possible to force a recalcitrant subject to comply with the law it is flouting, then that law is no more than an aspiration. At best, it will be a rational aspiration, but it will not truly be law. In fact, however, from the point of view of the frequency of violations, international law is treated with more respect than internal law. The idea that consensual norms are normally better complied with than those imposed, perhaps by force, is not one that would occur spontaneously to many people. But one has only to consider the number of cases in which the law is broken every day in a city such as, say, Naples, or for that matter the number of daily breaches of road traffic codes and laws that take place in any State you care to consider: the force of the point becomes plain at once. Moreover, the organised sanction of these breaches concern only an infinitely small number of cases. In relations between States, by contrast, as soon as there is a breach of international law, it tends to be identified immediately. Any violation, even a modest one, of an inter-State agreement or other international norm, at once takes on political proportions, affecting the honour and life of a collectivity, and bringing collective forces into play. Media attention is at once aroused. This shows the world only the violations of international law, completely ignoring the statistical question of how frequently they occur compared with the instances in which States fulfil their obligations under international law. Hence the erroneous impression is created that international law is not truly complied with. The foreign news pages of daily newspapers report the daily violations of international law, but it should be remembered that they report almost every violation. A newspaper that reported every violation of internal law would run to thousands of pages. And even then, one could be sure that 
a great number of violations would go unmentioned, since within every State a great number of breaches of the law pass unnoticed or unrecorded - and of course unpunished. This is not the case in international law: almost all breaches are visible, and almost all are noticed.

In the sections above, we have been considering the matter from a quantitative point of view. Let us now turn to the qualitative. Here the situation in international and internal law is almost identical. The maxim Ordnung im Kleinen, Unordnung im Grossen ${ }^{45}$ is broadly applied in international as in national law. Liberties taken with the law by the supreme organs of State, or by powerful groups such as economic conglomerates or strong unions, seldom meet any effective challenge or sanction. Considerable areas of constitutional law are not protected by sanctions or constraints. There is simply a problem about power, quite independently of the particular form of social organisation. The closer you get to the summit of power, the weaker the law becomes. The citadel of power is always to some extent impenetrable by the law. Interests considered vital at any particular moment fall through the legal net: de maximis non curat praetor; and perhaps also de maximis non curat lex.

The important thing here is to abandon ideas about international law being either effective or ineffective en bloc, and to turn instead to drawing up a proper inventory. International law covers a great number of different matters, each characterised by its own particular degree of effectiveness. As we all know, the law of armed conflict, i.e., the duties of States as to the means and methods of armed conflict, and as to the treatment of persons involved in it, is often violated, especially in non-international armed conflict. It would be naïve to expect otherwise. When the social order collapses, and those concerned are engaged in a struggle for survival, there will always be a tendency to override the limits, following the adage Not kennt kein Gebot - 'Necessity knows no law'. Even so, as Jean Pictet used to say, the law of conflict still has its uses if it succeeds in saving even a single life. In any event, there are other aspects to this question, other branches of international law that are habitually complied with and properly respected. An example is to be found in the field of technical matters that have little to do with politics. Take postal deliveries. Every time we receive a letter from another country, an international treaty (i.e., the Universal Postal Convention) does its work. In other words, international law comes into play. Were it not for the Convention, we would not receive letters from abroad because

45 'Order in minor aspects, disorder in fundamentals'; cf. A. Hold-Ferneck, Lehrbuch des Völkerrechts, vol. I, Vienna, 1930, p. 88. 
they would not be able to cross international frontiers. If we were to draw up an inventory of the workings of all the different branches of international law, that would highlight the fact that, although there are some branches whose efficacy is impaired (such as the law on nonrecourse to the use of force and the law on armed conflict), there are intermediate levels of efficacy (such as the law of treaties), and other branches that work very effectively indeed, particularly in technical fields. What is important is to take an overall view. It is true that the various branches of international law are not all of equal importance. One of the most important areas of international law is devoted to the preservation of the peace. As so well expressed in the first ever commentary on the United Nations (by L. M. Goodrich/E. Hambro ${ }^{46}$ ), the prohibition against resorting to force, and thus the maintenance of the peace, is the fundamental condition without which all the other objectives of the international law of the Charter (human rights, improving the conditions of the lives of peoples, peaceful resolution of disputes, etc.) will be unachievable. It is a particular weakness of international law that the enforcement of its most important rules is most visibly lagging behind legitimate expectations. But even there the law is not simply irrelevant: it will operate as a tool for action against the internationally illegal action, as the reactions after the annexation of Crimea (2014) again show. ${ }^{47}$

One needs also to remember that the overall assessment will naturally fluctuate from one period to the next. Like any other living organisation, international law has its relatively happy quiet periods, but also lives through fast-moving times when it has to undergo defeats, effect retreats and suffer other maladies. With the coming of World War I, some commentators pronounced its obsequies ${ }^{48}$ and similarly with World War II. Today we are again in crisis, as powerful Governments, previously upholders of international law, turn their faces away from it. Their main wish and motive is to free themselves from any constraints that might otherwise hamper their untrammelled unilateralism. These attitudes naturally increase the many international tensions that already existed. ${ }^{49}$

46 Charter of the United Nations, Commentary and Documents, 2nd edn, London, 1949, p. 93.

47 T. D. Grant, 'Annexation of Crimea', AJIL, vol. 109, 2015, pp. 68 et seq.

48 Cf. O. Nippold, Die Gestaltung des Völkerrechts nach dem Weltkriege, Zurich, 1917.

49 See Serge Sur, Le Conseil de sécurité dans l'après 11 septembre, Paris, 2004, pp. 88-9: 
Nevertheless, history does demonstrate that for each ebb-tide of internationalism there is a countervailing inflow. Grotius' great ' $D e$ iure belli ac pacis' (1625), today so much fêted as the cornerstone of modern international law, first saw the light of day as a result of the immense tribulations brought about by the Thirty Years War. The League of Nations Covenant (1919) was a response to World War I, and the UN Charter (1945) drew on the experience and lessons of World War II. Defeat and rebirth are twins.

Further, it is not generally realised that the time factor is such an important element in the application of international law. Where international law cannot deliver immediate results, it can nevertheless create obstacles which, obstinately persisted in, can - in the long run - weaken the opposing forces by a process of attrition. In temporal terms, international sanctions are slow-working. They involve cumulative action against a range of pressure points, using a panoply of means, all of which can take a long time to deliver results. Thus, international law is often used to counteract facts that have been created in defiance of it, bringing home to the wrongdoer the implications of its original illegality, and preventing it from quietly enjoying and digesting the benefits that would otherwise accrue from its violation. Strategies of this kind can bear fruit only as long-term exercises. Numerous examples illustrate the point - the liberation of the Baltic States annexed by the Soviet Union in 1940; the defeat of the aggressors of the 1930s (Japan, Italy, Germany); the long-term strategic struggle against South African apartheid, both in Namibia and in South Africa itself; etc. The efficacy of international law (and related international policies) must therefore often be judged over longer periods of time than when considering internal law.

Finally, it is important to remember that there are numerous forces encouraging States to respect the rules of international law; some of these forces do not operate with equal constraint for internal law. Without making any attempt to be exhaustive, we can mention the following:

Clearly, such an unequal and bellicose conception of international relations, even if it can be based on objectives that benefit some general interest ... is of such a kind as to create a climate of mistrust within the international community ... It is equally clear that such a conception cannot fail to encounter resistance, which may for a time be concealed, but sooner or later will inevitably make itself felt ... In any event, such a conception is pregnant with future conflict, and carries with it a strong danger of destabilising rather than pacifying the international scene [our translation]. 
(1) In internal law, the choice between observing the law and the temptation to violate it is made primarily by individuals acting in pursuit of their particular interests. A typical example would be the driver who, in his hurry, is weighing up whether to park his car in a no-parking zone. When it comes to international law, the decision whether to comply with international law is usually made by the civil servants in the chancelleries of the States concerned, acting for the perceived benefit of their States and not in their own private interests. They have no reason not to apply the rules of international law, just as they have no reason not to apply internal law. On the contrary, such an impersonal and disinterested decision of compliance will normally be quite automatic - unless, that is, important national policies start to interfere. Only a very small minority of such administrative decisions is affected by important national policy considerations.

(2) The rules of internal law are far more numerous than those of international law, and they are also far more detailed. Consider, for example, the meanderings of administrative regulations. Inevitably they lead to a far greater number of violations. International law, by contrast, contains on the whole fewer rules, and its rules are often less detailed. Many of them are more flexible than is the case under internal regulation, and violations are often more difficult to demonstrate, because the rules deliberately leave a wider margin of action. Where there are fewer rules, violations are necessarily less frequent. In a nutshell, sovereign States are 'freer' in the international field than the individual is within the complex structures of a modern State.

(3) The exercise of power presupposes a certain stability and predictability in the field of operation concerned. It suffices to observe how frequently political reversals, and sometimes even anarchy, hamper the foreign policy of States, even of great Powers. Therefore, the greatest Powers seek to establish a peace under their own hegemony: a pax romana, or nowadays a pax americana. Such Powers can, at most, make only relatively evanescent gains from international disorder, which prevents their stabilising their power and reaping the anticipated dividends. And what is true for the greatest Powers is even more true for medium-sized and smaller States. For such States, lacking as they do the muscular strength of the greater Powers, international law is an important protection, and they have a direct and immediate interest in strengthening it. Switzerland, for example, never fails to emphasise, in its official documents, that as a small State, it has a strong interest in the 
proper functioning of international law, and in compliance with that law by the international community. For these reasons, the violation of international law makes little or no sense for the vast majority of States in most situations. Their sense of the broader protection provided by international law to their essential interests thus operates as a powerful brake on any impulse they might have to commit particular violations.

(4) Reciprocity, too, is a powerful factor in encouraging States to conform to international legality. If State A violates a rule with regard to State B, it must then expect that State B will respond by suspending the application of another rule that may be of importance to State A. This calculation tends to make the violation of a rule of international law a less attractive proposition than it might otherwise seem. But reciprocity has different effects as between relatively weak and strong States. Furthermore, there exist also collective sanctions, collective counter-measures, sanctions imposed by an international organisation, etc. Here, even the strongest States may be exposed to a certain amount of danger, unless they can assemble a network of important allies. A superpower, however, will not be in this kind of danger. It should be added that even the worst of politicians are caught in the pincers of this kind of reciprocity: wasn't it the fear of reprisals that caused Hitler to deny himself the use of chemical weapons?

(5) A State violating international law faces more serious consequences if the nation is cohesive, and the State's individuality and honour count for a great deal. In such a State, breaches of international law will not simply pass unnoticed: the State will be exposed to the stigma and its reputation will be at risk. It will have to take account of the possibility (itself depending on the type of violation contemplated, and/or on public opinion) of pressures, from various elements within its national society, to return to conformity with international law. For such a State, highly important interests have to be at stake before it will incur such risks.

(6) The voluntary element predominates in international law, both as regards the creation of new law and in burdening States with particular obligations. To a considerable extent, international law is treaty-based, rather than being dependent on any kind of imposed legislation. Usually, therefore, obligations are incurred through the unilateral expression of the State's will, or by bilateral or multilateral agreement. So, for example, no State is subject to the compulsory jurisdiction of the International Court of Justice unless it has consented to it. The fact that such consent has been given 
then makes it much more likely that the Court's judgments will be complied with. When a State agrees to submit to the jurisdiction, it has already factored in the risk of losing one or more cases. If it is not prepared to accept the risk of unfavourable decisions, it simply refuses to consent to the jurisdiction. In the same way, the whole corpus of international law has a better chance of being complied with because it is by their own will that States enter into so many of their obligations. By contrast, in internal law this element of autonomy is to a considerable degree absent, so that the individual simply finds himself saddled, volens nolens, with a range of legal duties and obligations. In this situation, the temptation to elude them is inevitably greater, and if an individual yields to it, he may well be assisted by the relative anonymity of private life.

(7) It is often the case that a State will make a more rational calculation of the risks of violating international law than will an individual considering, under a momentary influence or passion, whether to commit a breach of internal law. This is yet another element of restraint that comes into operation when States are tempted to violate international law.

(8) International law benefits from the fact that a whole series of its rules are incorporated into the internal laws of States. In this way they are supported by internal law enforcement mechanisms. So it is that treaties on human rights, or simply concerned with the rights of individuals, are taken into the domestic law of the States ratifying the relevant treaties. The organs of the State will then see to it, with whatever degree of efficiency they possess, that the relevant rules are carried into actual application. If there is then a violation of the rule, it will be first and foremost a violation of internal law, and only indirectly a violation of international law. This point should perhaps be considered more often. International law on human rights is often said to be weak. Perhaps the accusation should first be levelled at internal law. That, after all, is where the disfunctionality first manifests itself.

All these factors (and there are others) amount to pressures favourable to spontaneous respect for and application of international law.

\section{The Distinction Between Legal Norms and Moral or 'Courtesy' Rules}

We now return for a moment to the vexed and confusing distinctions between the law of nations and international morality on the one hand, 
and between the law of nations and international courtesy on the other. In rejecting the reduction of the law of nations to international morality or to comitas gentium, we are in no way denying that morality and courtesy have their parts to play in the ordering of international relations, just as they do in the ordering of interpersonal relations within States. In every community, and thus also within the community of nations, law is only one set of norms amongst others, which include religion, morality and courtesy. These different classes of norms are not always sufficiently distinguished from each other, and this is particularly true of morality and courtesy. What, then, is the right way to distinguish between these concepts?

In our view, while morality orders and governs conduct from the point of view of man's ultimate destiny and the quest for his fullest perfection as a being endowed with reason, law orders and governs conduct from the point of view of conformity with the common good of society, seeking to harmonise individual activities in light of the requirements of justice. This is the reason why morality is concerned only with the individual conscience, whereas law, by contrast, is able to take account not only the acts of the individual as such, but also the acts of collectivities forming new units of decision-making within the spheres of action proper to them. This also explains why the field of morality is wider than that of law, and why its centre of gravity is internal to the individual, whereas law is, first and foremost, concerned with the external repercussions of peoples' actions, or with their social impact. Admittedly, the content of moral and concrete legal rules is often identical, because the material object of the two is to a considerable extent identical. Since man lives in society, he has duties to his fellows, and that dictates social morality. One element of social morality is international morality, which prescribes certain duties for mankind, and especially for governments in their international relations. But although the material object coincides, and a fortiori so do the concrete precepts, there will always be a difference of perspective as regards what scholastic philosophy calls the 'formal object'.

As regards courtesy, which eminent authors such as Giorgio del Vecchio and Gustav Radbruch do not accept as an autonomous normative category, the surest criterion for distinguishing it from law perhaps consists in the fact that, spontaneously generated within society, it obtains its binding force solely from public opinion, and that, considered overall, it applies to secondary aspects of a society's life. Like morality and law, its material object can be international relations: we then have the comitas gentium. 
It follows, from this brief examination of the question, that morality and courtesy play a part, and an important part, in international life, but that nevertheless they should not be confused with international law, not even when the latter is imperfect. What separates these three different kinds of norm is not a greater or lesser degree of perfection, but their different perspectives and finalities. 